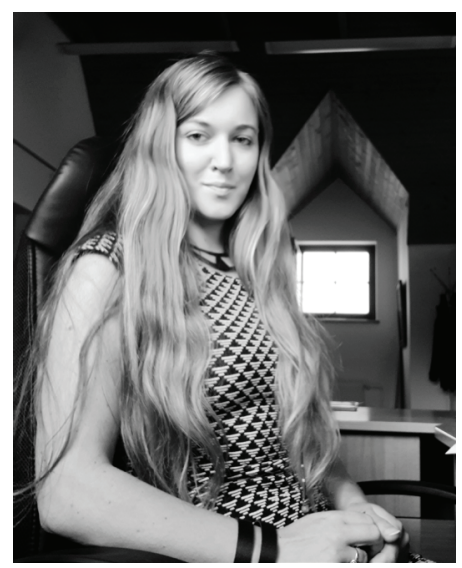

Gintarè Dusevičiūtè-Neimontienè - Vytauto Didžiojo universiteto etnologijos doktorantė

Moksliniai interesai: modernioji etnologija, tradicijų transformacijos

El.paštas: g.neimontiene@gmail.com

Gintarè Dusevičiūtè-Neimontienè - $\mathrm{PhD}$ student in Ethnology, Vytautas Magnus University

Research interests: modern ethnology, tradition transformations

E-mail: g.neimontiene@gmail.com

\title{
Gintarè Dusevičiūtè-Neimontienè
}

Vytauto Didžiojo universitetas

\author{
POSTMODERNUS ISTORINES \\ REKONSTRUKCIJOS JUDËIMAS LIETUVOJE
}

\section{Anotacija}

Šiame straipsnyje trumpai apžvelgiamas istorinès rekonstrukcijos judejjimas pasaulyje. Nacionaliniai šio reiškinio ypatumai išryškinami analizuojant istorinès rekonstrukcijos judèjimo prielaidas ir aplinkybes Lietuvoje. Judejjimo formavimosi ir raidos aplinkybès aptariamos pirmųjų istorinès rekonstrukcijos klubų ir istorinės rekonstrukcijos renginių kontekste. Darbo pagrindą sudaro lauko tyrimų metu (2015-2018 m.) surinkta medžiaga, pateikejjų apklausa ir interviu. Duomenų analizei taikyti istorinis lyginamasis ir analizès metodai. Remiantis atliktais tyrimais, istorinès rekonstrukcijos judejimo pradžia Lietuvoje siekia XX a. 9-ąi dešimtmetį. Tam įtakos turèjo tiek XX a. 7-ajame dešimtmetyje Europoje susiformavusi folklorinio judejjimo banga, pasiekusi ir tuometinę Lietuvą, tiek $1990 \mathrm{~m}$. valstybingumo atkūrimas ir siekis tinkamai pristatyti ilgametę Lietuvos valstybès istoriją. Medijos (ypač internetas) bei santykiai su artimiausių kaimyninių valstybių (Latvijos, Lenkijos, Estijos, Baltarusijos ir Rusijos) klubais paspartino judejjimo raidą ir populiarumą. Atlikus tyrimą, išsiskyrė keturi istorinès rekonstrukcijos laikotarpiai: 1. Baltų; 2. Viduramžių; 3. Napoleonmečio ir 4. XX amžiaus. Nors istorijos atkūrimo procese pasirenkamos gana bendros temos (pvz., viduramžiai), tačiau dažniausiai ị šią temą integruojama lokaliné, regioninè, nacionaliné Lietuvos istorija ir jai priklausantys artefaktai. Baltų ir jų genčių (jotvingių, kuršių) klestejjimo laikotarpis, LDK kūrimosi ir gyvavimo laikotarpis bei partizaninis pasipriešinimas yra temos, istorinès rekonstrukcijos judejjime žyminčios Lietuvos išskirtinumą.

PAGRINDINIAI ŽODŽIAI: istorinès rekonstrukcijos judejjimas, Lietuva, rekonstruktorius, gyvoji istorija.

\section{Abstract}

The article discusses the beginning, assumptions and dispersion of the historical reenactment movement in the world. National peculiarities of the phenomenon are highlighted by presenting the preconditions for and circumstances of the historical reconstruction movement in Lithuania. 
Features of the phenomenon are analysed in the formation of the first historical reconstruction clubs and the first festivals. The basis for this work is fieldwork material collected during 20152018 , in the form of surveys and interviews with respondents. The data was processed by applying historical comparative and analytical methods. According to the data, the beginning of the historical reenactment movement in Lithuania started in the 1980s. This was influenced by Lithuania's restitution of its statehood in the 1990s after Soviet suppression, and the desire to properly present the long history of the state. The folklore movement that started around the 1970s was still in existence, and influenced the start of the historical reenactment movement. The media (especially the Internet) and relations with foreign clubs (in Latvia, Poland, Estonia, Belarus and Russia) increased the development and popularity of movement. The analysis of the data has indicated the following main historical reenactment periods: the Balts, the Middle Ages, the Napoleonic era, the First and the Second World War, and the resistance. In the reenactment of general themes (such as Medieval), the local, regional and national history and artefacts are employed. The period of the Balts and Baltic tribes (Yotvingians, Curonians), the period of the creation and prosperity of the Grand Duchy of Lithuania, and the partisan resistance, are themes by which the historical reenactment movement stands out.

KEY WORDS: reenactment in Lithuania, reenactor, living history.

DOI: http://dx.doi.org/10.15181/rh.v26i0.2049

I v a d a s

Per pastaruosius kelis dešimtmečius tiek Europoje, tiek ir daugelyje kitų pasaulio valstybių pastebimai padaugejjo istorinio turinio švenčių ir renginių. Šiuose renginiuose žmonès dèvi istoriniais kostiumais, pristato karybos technikas, amatus (juvelyriką, puodininkystę, kalvystę ir kt.) ar šokius. Atkuriami įvairūs laikotarpiai: nuo akmens amžiaus iki XX a. vidurio. Atkurtas vienas ar kitas laikotarpis, jo detalès naudojami ne tik istorinių renginių metu, bet ir statant filmus, filmuojant laidas ar reklaminius klipus. Šio judejimo geografinès ir tematinès ribos plečiasi, reiškinys neišvengiamai kinta, igaudamas vis naujų raiškos formų.

Istorijos atkūrimo reiškinys neaplenkia ir Lietuvos. Geriausi to pavyzdžiai „Kauno Hanza dienos“, „Viduramžių šventè“ Trakuose ir daugelis kitų panašaus pobūdžio renginių. Praeities ar konkrečių ịvykių minejjimas pasirenkant toki formatą - tai ne tik populiari pramoga visuomenei, bet kartu galimybé formuoti ir stiprinti lokalini ar nacionalini tapatumus. Patraukliomis formomis vykstantis istorijos rekonstravimas tapo įdomiu ir aktualiu, tačiau ne mažiau klausimų keliančiu reiškiniu.

Problematika. Nors istorinès rekonstrukcijos judèjimas yra globalus reiškinys, tačiau iki šiol jam nèra skirta pakankamai dėmesio. Neaišku, kokiomis aplinkybėmis reiškinys susiformavo, kaip vyko jo sklaida ir adaptacija prie lokalinio Lietuvos konteksto. Ką galètume laikyti istorinès rekonstrukcijos atskaitos tašku Lietuvoje? Taip pat kokie yra atkuriami laikotarpiai, temos? Galiausiai, ar istorinès rekonstrukcijos judejjimas Lietuvoje yra savitas? 
Šio straipsnio objektas - istorinès rekonstrukcijos judejjimo formavimasis Lietuvoje.

Straipsnyje siekiama apžvelgti istorines rekonstrukcijos judejjimo ištakas pasaulyje ir nustatyti šio reiškinio formavimosi aplinkybes Lietuvoje. Remiantis tyrimų rezultatais, bus siekiama atskleisti nacionalinius šio reiškinio ypatumus.

Darbe keliami uždaviniai:

1. Apžvelgti istorinès rekonstrukcijos judejjimo ištakas pasaulyje, išskiriant reikšmingiausių organizacijų, dariusių itaką istorinès rekonstrukcijos raidos kryptims ir tendencijoms, indèli.

2. Aptarti istorines reiškinio formavimosi, sklaidos aplinkybes.

3. Nustatyti pagrindines istorinès rekonstrukcijos judejjimo kryptis Lietuvoje.

Darbo metodologija. Šiame darbe pristatomi 2015-2018 m. autorès atlikto lauko tyrimo rezultatai. Minètu laikotarpiu lankytasi įvairiuose istoriniuose festivaliuose, šventėse ir renginiuose (iš viso 23), susijusiuose su istorine rekonstrukcija. Stebejjimo metu buvo kaupiama vizualinè (fotografijų ir vaizdo) medžiaga. Nuo 2014 m. vykdytas dalyvaujamasis stebejimas: amato (juostų vijimo) demonstravimas ir viduramžių šokių pasirodymai (kartu su kolektyvu „Saltus Gladii“). Kita tyrimo dalis susideda iš rekonstruktorių klubo narių ir pavienių asmenų, dalyvaujančių šiame judejjime, anketavimo. Anketą sudarè 28 klausimai. Apklausai naudota platforma www.manoapklausa.lt ${ }^{1}$. Taip pat duomenys rinkti platinant anketą Facebook rekonstruktorių grupèse ir siunčiant el. paštu. Iš viso gauti 32 atsakymai. Lygiagrečiai duomenys, pasitelkus „sniego kamuolio“ metodą, buvo pildyti giluminiais, pusiau struktūruotais interviu. Šiuo metodu apklaustas 31 informuotas pateikejas. Iš viso tyrimas apima 63 pateikejuc atsakymus. Iš ju 42 vyrai ir 21 moteris. Papildoma informacija rinkta istorinès rekonstrukcijos klubų internetinėse svetainėse ir socialinio tinklo Facebook paskyrose.

Duomenims apibendrinti taikyti analizès ir istorinis lyginamasis metodai. Pastarojo metodo taikymas leidžia gretinti istorinès rekonstrukcijos reiškini skirtingais jo gyvavimo laikotarpiais ir diachroniškai išskirti svarbiausias raidos tendencijas. Istorinis reiškinys plačiau analizuojamas Lietuvos kontekste, nagrinejjant postmoderniosios rekonstrukcijos kūrimosi ir raidos laikotarpi nuo XX a. 9-ojo dešimtmečio iki šių dienų. Surinkti duomenys saugomi Vytauto Didžiojo universiteto Kultūrų studiju katedros rankraštyne (VDU ER bylos Nr. 2677).

1 Manoapklausa.lt. Interneto svetainè, kurioje buvo skelbta anketa „Istorinè rekonstrukcija Lietuvoje“. Prieiga internetu: <http://www.manoapklausa.lt/apklausa/826847747/1/> [žiūrèta 201904 25]. 
Tyrimų apžvalga

Istorinès rekonstrukcijos (arba gyvosios istorijos) judejimas jau ne vieną dešimtmeti atsiduria mokslininkų dèmesio centre. Reiškinys tapo dar vienu skirtingų mokslo disciplinų (istorijos, etnologijos, antropologijos, sociologijos, archeologijos) domèjimosi ir tyrimo objektu. Jam nagrinèti taikytos skirtingos metodologijos ir teorinès prieigos.

Istorinès rekonstrukcijos reiškinys daugiau mokslininkų dėmesio sulaukè XX a. 9-ajame dešimtmetyje. Stephenas Gappsas savo darbuose (Gapps 2002; 2009) analizavo istorinès rekonstrukcijos fenomeno raidą nuo XIX a. pabaigos iki XX a. pabaigos. Autorius nagrinèjo ankstyvąsias istorinės rekonstrukcijos apraiškas, kurias siejo su istorinės tematikos paradais ir įvairiais istorinių įvykiu minejimais. Būtent S. Gappso darbe buvo nubrèžta skirtis tarp moderniosios ir postmoderniosios istorinės rekonstrukcijos. Ši kaita iliustruojama Australijos pavyzdžiu. Istorinės rekonstrukcijos reiškinio kilmę ir pagrindinius jo bruožus savo darbuose nagrinejo V. Agnew (2004; 2007). Pasak autorès, šis kultūrinis reiškinys, tapęs visuotiniu, neretai svyruojantis tarp realios ir įsivaizduojamos praeities, pirmiausia siejasi su individualizmu (Agnew 2004, 327). Straipsniu rinktineje „Historical Reenactment: From Realism to the Affective Turn“ (2010) bandyta pateikti tarpdisciplininį reiškinio apibrèžimą, keliant filosofinius, istorinius, antropologinius teorinio ir praktinio pobūdžio klausimus.

Galima paminèti ir kitas, šiame straipsnyje ne tokias svarbias, tačiau istorinès rekonstrukcijos tyrimų kontekste reikšmingas analizės perpektyvas, padėsiančias aiškiau suvokti patị reiškinį. Materialinè kultūra ir jos autentiškumas yra bene dažniausiai tyrejjų pasirenkama analizès perspektyva. Ją nagrinèjo minètasis S. Gappsas (2009), Stephanie K. Decker (2010) ir Dawidas Kobiałka (2013), materialinès kultūros atkūrimą laikydami visuomenei priimtina nostalgijos forma, reikalinga bendrai istorinei atminčiai palaikyti. Tikètina, jog tokia materialinès kultūros ir autentiškumo samprata yra būdinga ir istorinès rekonstrukcijos dalyviams Lietuvoje. Kiti mokslininkai kèlè autentiškumo ir naratyvų reikšmės klausimus (Handler, Saxton 1988; Manson 2004; Micula 2015).

Lietuvos mokslininkai istorinès rekonstrukcijos reiškinio analizei iki šiol nėra skyrę pakankamai dèmesio. Internetiniuose naujienų portaluose galima rasti festivalių, švenčių aprašymų, rekonstruktorių interviu ir pan $^{2}$. Tomo Sutkaičio

2 Pavyzdžiui, naujienuc portalas „Alkas“. Prieiga internetu: <http://alkas.lt/2015/09/18/kviecia-kasmetine-istorine-rekonstrukcija-medininku-pilyje/> [žiūrèta 2018-10-20]; Istorinèmis ir kultūros temomis publikacijas leidžiantis laikraštis „Voruta“. Prieiga internetu: <http://www. voruta.lt/isorines-rekonstrukcijos-brolija-vilkatlakai/> [žiūrèta 201812 20]; Daiva Jankauskaitè. Suaugusių žmonių žaidimas - grižti ì praeitị. Naujienų portalas „Delfi“. Prieiga internetu: $<$ http://www.delfi.lt/pramogos/kultura/suaugusiu-zmoniu-zaidimas-grizti-i-praeiti.d?id=143 15484\#ixzz3VFeQagla> [žiūrèta 201905 15] ir kt. 
(2010) straipsnis yra vienas iš pirmųju nuoseklių bandymų supažindinti su klubo „Vilkatlakai“ atsiradimo istorija, atskleisti klubo narių pasaulèžiūrą ir pagrindines veiklos formas. Kartu tai yra bandymas pateikti retrospektyvinę ne tik paties klubo, bet ir rekonstrukcijos fenomeno sampratą. Autorius išskiria grupès kultūrinio identiteto ypatumus, paaiškina vidinę jos struktūrą, apibrèžia materialinès ir dvasinès kultūros vietą bei veiklos lauką. Plačiau istorinès rekonstrukcijos temą nagrinèjo etnologè Agnè Kalèdienè, savo darbuose (2018a; 2018b) istorinès rekonstrukcijos klubus analizavusi subkultūrinès grupès raiškos ir identiteto kontekste. Kaip pagrindinius rekonstruktorių grupę vienijančius veiksnius autorė išskiria domėjimąsi istorija, nacionalizmą ir pagonišką religiją. A. Kalèdienės stebèjimai ir interviu buvo atlikti su jau minèto klubo „Vilkatlakai“ nariais, todèl neatskleidžia istorinès rekonstrukcijos reiškinio visumos. Renatas Delis (2005, 187-225), nagrinèjęs neopagonybès judèjimo apraiškas posovietinès Lietuvos kontekste, taip pat mini istorinès rekonstrukcijos dalyvius. „Vilkatlaku“ klubo ir kiti panašaus (baltų) laikotarpio istorinès rekonstrukcijos klubų nariai laikyti svarbia tuometinio neopagoniškojo judejimo dalimi. Šio mokslininko darbe yra išryškinama skirtis tarp autentiškumo ir neautentiškumo, atskleidžiama per archeologinio (istorinio) kostiumo dèvejimo ypatumus (Delis 2006, 187-225).

Vis dèlto istorinès rekonstrukcijos laukas Lietuvoje yra gerokai platesnis. Jame veikia ne vienas klubas, organizacija, atkuriami ívairūs laikotarpiai ir veiklos. Pažymètina, kad aptartuose tyrimuose daugiausia dèmesio skiriama seniausio (baltų) laikotarpio rekonstrukcijoms, todẻl sunku nustatyti, ar reiškinio sklaida vyko panašiu laikotarpiu ir veikiant panašioms sąlygoms. Nors A. Kalėdienė prie istorinès rekonstrukcijos grupiu priskiria ir senosios (prigimtinės) baltų religijos išpažinèjus („Romuvos“ bendruomenè), šio darbo autorè dvasinès kultūros atkūrimo nelaiko istorine rekonstrukcija, veikiau jos dalimi, turejjusia itakos reiškinio raidai.

\section{Pagrindines squokos}

Istorinés rekonstrukcijos (angl. historical reenactment) judëjimas - globalus šiuolaikinès visuomenès kultūrinis ir socialinis reiškinys, kuris per pastaruosius kelis dešimtmečius tapo judẻjimu. Judejjimo pagrindą sudaro pasirinkto istorinio laikotarpio veiklos ir su ja susijusios materialinès kultūros objektų atkūrimas ${ }^{3}$.

Rekonstruktorius $(-\dot{e})$ - asmuo, aktyviai dalyvaujantis istorinès rekonstrukcijos veikloje (atkuriantis istorijos objektus ir / ar senąsias technologijas). Remiantis tyrimo duomenimis, rekonstruktoriais save laiko 78 proc. (49) pateikejjų. Laisvasis rekonstruktorius - dalyvaujantis istorinès rekonstrukcijos veikloje, tačiau nepriskiriantis savęs jokiai konkrečiai organizacijai.

3 Šiame straipsnyje gyvosios istorijos (angl. living history) terminas vartojamas kaip istorinès rekonstrukcijos sinonimas. 
Klubas - pagrindinis organizacinis vienetas, kuriame vystoma įvairi, nuo klubo pobūdžio (amatų, karybos, pramogų) ir atkuriamo laikotarpio priklausanti veikla. Klubų tematinè iqvairovè plati, susijusi su vietos, regiono, genties ar pasaulio istorijos atkūrimu.

\section{Istorinès rekonstrukcijos judejimo ištakos pasaulyje}

Noras atpasakoti, vizualiai atkurti praeities įvykius ir jų detales žinomas jau nuo antikos laikų, kai svarbių mūšių pergalèms pažymèti buvo statomi specialūs istorinius įvykius vaizduojantys vaidinimai. Istorijos įvykių atkartojimas buvo tęsiamas ir vèlesniais laikais, ypač viduramžiais. Biblinių siužetų inscenizacijas (religines procesijas, vaidinimus) taip pat būtuc galima laikyti istorinès rekonstrukcijos pirmtakais.

Per pastarąij šimtmetị įvyko itin daug pokyčių: gerejo ekonominès sąlygos, vyko intensyvi technologiju raida, informacijos sparta pasiekè neregètą greitį ir t. t. Šie pokyčiai sudarè prielaidas iki šiol nematyto masto istorinès rekonstrukcijos judejimui susiformuoti. S. Gappsas rekonstrukcijos judejjimo užuomazgas sieja su XX a. 7-ajame dešimtmetyje JAV vykusiais procesais Amerikos pilietinio karo rekonstrukcija (Gapps 2002, 39). Žinoma, šis judejjimas neatsirado staiga, nes ir iki tol tiek JAV, tiek kitose pasaulio valstybèse būta nemažai istorinių i̇vykių atkūrimo, istorinių paradų ir pan. Anot minèto autoriaus, XIX a. istoriniai paradai, svarbių datų minèjimai, o vèliau ir pirmieji gyvosios istorijos muziejai padejjo modernios istorinės rekonstrukcijos reiškinio susiformavimo bei tolesnès jo raidos pagrindus. Nuo 7-ojo dešimtmečio istorijos vaizdavimas tiek JAV, tiek ir kitose pasaulio valstybėse ima įgauti kitokią formą. Istorijos reprezentavimas iki tol buvo vykdomas oficialių valstybès institucijų, atsakingų už bendros istorinès atminties palaikymą, pavyzdžiui, kultūros centrų, muziejų. Istorinès atminties tęstinumo iniciatyvą perėmè organizuotos grupès ir pavieniai asmenys, suinteresuoti aktualizavimu tuc istorijos momentų, kurie, jų nuomone, atrodė reikšmingiausi. Ilgainiui atsirado mūšių, gyvosios istorijos scenų masinių inscenizacijų. Rekonstruktoriai prisiemė atsakomybę už tinkamą istorijos reprezentavimą ir visuomenès edukaciją, neslëpdami savo asmeninio susidomejjimo rekonstruojamu laikotarpiu ar konkrečiu objektu. Naudojami istoriniai kostiumai tapo ne tik teatro atributu, bet ir aiškiai pabrèžiamo tapatumo dalimi. Dèl susidoméjimo populiariosios kultūros istorijos atvaizdavimu buvo papildytas iki tol buvęs gana siauras jos temų bei atkuriamų istorinių asmenybių sąrašas (Gapps 2002, 39). Reiškinys, besiplečiantis tiek tematiškai, tiek ir geografiškai, tapo judejjimu. Daria Radchenko (2006), remdamasi Rusijos pavyzdžiu, taip pat pažymi, jog istorinè rekonstrukcija XXI a. pradžioje per 
dešimtmetį išaugo i gyvosios istorijos judejjimą. Postmodernaus laikotarpio ypatybès leido istoriją fragmentuoti ir sudarinèti individualius istorijos rinkinius. Rekonstrukcijos centre atsiduria individualizuotas poreikis atkurti pasirinktą istorini fragmentą, kuriant ryšį tarp praeities ir dabarties. Toks postmodernus istorinès rekonstrukcijos judejjimas panašiu laiku išplito ir Didžioje Britanijoje, o netrukus pasiekè ir daugeli kitų Vakarų bei Šiaurès Europos šalių.

V. Agnew $(2004,328)$ pažymi, kad įvairūs „realybès proveržiai“, tokie kaip televizijos serialas „The Real World“ („Realusis pasaulis“), istorinès realybès televizijos programa „The 1900 House“ (,1900 m. Namai“) ir kelioniu filmas „The Ship“ („Laivas“), tapo istorinès rekonstrukcijos judejjimą paskatinusia pradžia. Šiuo metu visame pasaulyje populiarūs serialai „Vikingai“ ir „Sostų karai“ ¡̨kvepia ịsitraukti ị istorinės rekonstrukcijos judèjimą, nors ilgamečiu rekonstruktorių yra stipriai kritikuojami dèl to, kad neatitinka istorinio tikslumo.

Prie judejimo sklaidos nemažai prisidejo ir konkrečios organizacijos, tokios kaip SCA (angl. The Society for Creative Anachronism) ir LARPG (angl. Live Action Role Playing Game). Pastaroji, LARPG, - gyvas vaidmenų žaidimas. Jo dabartinè samprata susiformavo XX a. antrojoje puseje $e^{4}$. Žaidejai - larperiai ar larpai - dažniausiai pasirenka atkurti fantasy žanro ịkvèptą personažą (pvz., elfą), kuris pagal iš anksto suderintą siužetą vaidina savo vaidmenį. Žiūrovai į šį personažų ir situacijų atkūrimą nėra įtraukiami. Itin didelę įtaką šiam judèjimui turejjo jau minètos tarptautinès organizacijos SCA įkūrimas JAV 1966 m. Jos veikla daugiausia buvo ir tebėra orientuota į viduramžiu Europos (iki XVII a.) istorijos atkūrimą ir populiarinimąa Nuo XX a. 8-9-ojo dešimtmečių SCA tapo gerai žinoma daugelyje Vakarų ir Šiaurès Europos valstybių. Tačiau anachronizmas reiškia, kad istorinis laikotarpio tikslumas nėra svarbus. Kodèl SCA turejjo tokią didelę ịtaką istorinès rekonstrukcijos raidai? Didžiojoje Britanijoje ir Švedijoje ši organizacija buvo daugelio klubų, susiformavusių per pastaruosius kelis dešimtmečius, atspirties taškas ir veiklos pradžia.

Be to, reiškinio formavimąsi paspartino ir po atviru dangumi (angl. openair) įsikūrusių muziejų atsiradimas, kuris per pastaruosius kelis dešimtmečius itin išpopuliarejo visame pasaulyje (Kobiałka 2013, 142). Muziejai, stengdamiesi pritraukti didesnị lankytojų skaičių, turimus eksponatus ėmėsi pristatyti iliustruodami gyvomis praeities gyvensenos ir buities detalèmis. Iki šiol muziejuose

4 Daugiau informacijos apie šị užsièmimą galima rasti LAYCOC, P. Joseph. Dangerous Games: What the Moral Panic over Role-Playing Games Says about Game, Religion and Imagined Worlds. University of California Press, 2015.

5 Remiantis jų oficialioje svetainėje paskelbtais duomenimis, dabartinis „žinomas“ pasaulis yra padalintas į 20 karalysčių. Šiuo metu organizacija vienija 30000 narių visame pasaulyje. SCA interneto svetainè. Prieiga internetu: <http://www.sca.org/> [žiūrèta 201811 29]. 
kuriamos erdvès, kuriose galima stebèti ir išbandyti senovišką audimo techniką, rašymą plunksna ar kitą praeityje naudotą techniką ar amatą.

Istorijos atkūrimu (ar kolekcionavimu) užsiimantys pavieniai asmenys, turèdami panašių tikslų ir idejjų (tarp kurių svarbiausi - atkurti istoriją), ėmė burtis i įvairias organizacijas ir telkti istorinès rekonstrukcijos entuziastus. İsikūrus klubams, palengvejjo disponavimo istorine, archeologine medžiaga procesas. Sklaidą palengvino ir šiuolaikinių medijų, ypač socialinių tinklų, teikiamos galimybès, leidžiančios užmegzti ryšius su panašaus pobūdžio klubais tiek savo šalyje, tiek už jos ribų. Iki šiol visame pasaulyje vykstantys istorinès rekonstrukcijos renginiai yra ne tik dar viena efektyvi šios veiklos populiarinimo ir sklaidos forma, bet kartu konkretus ir apčiuopiamas judejimo veiklos rezultatas.

Istorinès rekonstrukcijos judéjimo raida ir sklaida Lietuvoje

1985 m. Michailui Gorbačiovui tapus Sovietų Sąjungos lyderiu, visoje Sovietų Sąungoje ir Lietuvoje įsivyravo perestroikos (persitvarkymo) nuotaikos. Susikloste palankios sąlygos burtis ị įvairius nacionalinio ir istorinio pobūdžio klubus, bendruomenes bei iniciatyvines grupes.

Istorinès rekonstrukcijos judèjimo užuomazgos Lietuvoje susijusios su senosios muzikos ir šokiu ansamblio „Banchetto Musicale“ įkūrimu 1986 m. Tai buvo pirmasis kolektyvas Lietuvoje, užsibrèžęs tikslą atkurti LDK ir kitų Vakarų Europos kraštų Renesanso laikotarpị ir tokiu būdu skleisti autentišką senųjų amžių dvasią̧ . „Banchetto Musicale“ buvo labiau orientuotas ị performanso atlikimą ir pasirodymus nei į istorinių detalių tikslumą. Istorija paremtų klubų susiformavimą dar labiau paskatino tuometiniai Lietuvos persitvarkymo sąūjžio formavimosi ir veiklos procesai. Tikrosios istorinès rekonstrukcijos pradžia reikètų laikyti 1989 m. Kauno karo istorijos klubo įkūrimą (toliau KIK) (VDU ER 2677, interviu Nr. 30). Jo pradininkas ir ilgametis vadovas - Arvydas Pociūnas. Pagrindinis šio klubo siekis buvo reprezentuoti karinę istorinę jungtị tarp naujai atgimusios Lietuvos ir LDK laikų valstybès. 1990-aisiais, atkūrus Lietuvos nepriklausomybę, klubo veikla pakito, nes didelè dalis buvusių klubo narių pradẻjo dirbti besikuriančiose valstybinėse institucijose, ypač krašto apsaugoje. Tęsiant pradètą KIK veiklą, toliau buvo gilinamasi į istorijos subtilybes, tapusias kiekvieno klubo nario pareiga ir reikšmingu indèliu ị Lietuvos istorijos pažinimą. KIK nariai rengdavo paskaitas (apie istorinị kontekstą, aprangos detales, ginkluotę) ir jas pristatydavo vieni kitiems.

6 „Bancheto Musicale“- muzikos ir šokių ansamblis. Prieiga internetu: $<$ http://banchettomusicale. 1t/> [žiūrèta 201905 15]. 
Algimantas Daugirdas, vienas iš klubo senbuvių, minèjo, jog 1992 m. klubo iniciatyva buvo organizuotas pirmasis oficialus istorinès rekonstrukcijos renginys, skirtas 1812 m. ìvykiams Kaune paminèti - Napoleono armijos persikèlimas ties Jiesios piliakalniu (vadinamu ir Napoleono kalnu). Remiantis asmeniniais kontaktais ir užsienyje matytais istorinès rekonstrukcijos renginiu pavyzdžiais, buvo pakviesti Napoleono armiją rekonstruojantys klubai iš Latvijos ir Rusijos. Rekonstruktoriai, simuliuodami istorinę situaciją, atliko prancūzų kariuomenès persikèlimą valtimis per Nemuną. Bendras renginyje dalyvavusių rekonstruktorių skaičius siekè apie 50 dalyvių. Tuo metu KIK atliko ne dalyvio, o renginio organizatoriaus funkciją, kadangi dar neturejo istorinių kostiumų (uniformų) vieno iš svarbiausių istorinès rekonstrukcijos elementų, nebuvo aiškiai apibrèžtas ir pats atkuriamasis laikotarpis. Galiausiai 1994 m. klubo veikla buvo koncentruota ị XVIII a. pabaigą, t. y. paskutinį LDK gyvavimo laikotarpị, trukusi iki $1791 \mathrm{~m}$. Be jau minèto renginio, $1996 \mathrm{~m}$. Kaune buvo organizuota Žalgirio mūšio inscenizacija, o 1997 m. birželio 21 d. Kauno Santakoje pirmą kartą ịvyko Deltuvos mūšio rekonstrukcija (VDU ER 2677, interviu Nr. 26, 2018).

1996 m. veiklą pradejo klubas „Vilkatlakai“, kuris nuo 2001 m. tapo oficialia organizacija. Šios grupès susiformavimo ištakų reikètų ieškoti jaunimo „Baltuvos“ organizacijoje (Ramanauskaitè 2002, 97; Delis 2006, 195). Baltų pasaulèžiūra ir tradicijų puoselejjimu grịsta jaunimo organizacija ėmè tarpusavyje derinti tiek dvasinę, tiek materialinę istorijos atkūrimo pusę (Sutkaitis 2010, 54). Klubo veiklos atskaitos tašku laikomas 1996 m. rugsejjo 22 d. paminètas Saulès mūšio 760-ies metu jubiliejus ${ }^{7}$. Nors „Vilkatlakų“ klubas vis dar gyvuoja, tačiau dèl asmeninių ir vertybinių nesutarimų jo narių skaičius stipriai sumažèjęs ${ }^{8}$. XXI a. pradžioje èmė rastis ir daugiau šị laikotarpi rekonstruojančių klubų: „Kovarnis“ (2001), „Varingis“ (2003), „Karionys“ (2004), „Sūduvos Tauras“ (2012) ir „Leitgiris“ (2012). Tiesa, būta bandymų atkurti ir vikingų laikotarpi. Tokios krypties èmèsi klubas „Utgardas“, įkurtas 2005 m. Vis dẻlto „,porą žiemų peržiemoję, dalis klubo vyrų pajuto protėvių šauksmą ir nusprende pradèti rekonstruoti baltų gentis, įsigilinti ị savo šalies istoriją “9. Tai rodo, jog ideologiniai nesutarimai (atkurti baltus ar vikingus) èmè ryškèti dar klubo formavimosi stadijoje. Aptariamojo laikotarpio prioritetu Lietuvoje išlieka baltų ir jų genčių rekonstrukcijos.

7 „Vilkatlakai“ - senovés baltų kovų brolija. Prieiga internetu: <http://www.vilkatlakai.lt/veikla> [žiūrèta 201904 02].

8 Etnologè A. Kalèdienė disertacijoje „Naujųjų baltų subkultūrinio lauko atsiradimas ir raida“ nurodè, kad 2016 m. klubo veikloje dalyvavo šeši nariai, o vidinè struktūra ir elgesio taisyklès tiriamuoju laikotarpiu jau nebėra tokios griežtos. Po klubo skilimo $(2014 \mathrm{~m}$.) keletas buvusiu šio klubo narių tapo kitų klubų ịkūrèjais ir lyderiais: „Jotvos sūnūs“, „Pilsota“ ir „Kauno kuopa“.

9 ,Utgardas“ - gyvosios istorijos klubas. Prieiga internetu: $<$ http://www.utgardas.lt/?kur=apiemus $>$ [žiūrèta 20190402$]$. 
XXI a. pradžioje èmé formuotis ir viduramžių laikotarpi rekonstruojantys klubai. Pradininkas ir iki šiol didžiausias viduramžių laikotarpio rekonstrukcijos klubas - „Viduramžių pasiuntiniai“"10. Kalbẻdamas apie šio klubo priešistorę, vadovas Karolis Jankauskas mini, jog apie 2000 m. Lietuvoje veikè nedidelè fantastų judejjimo grupelè, organizavusi lauko vaidmenų žaidimus (VDU ER 2677, interviu Nr. 24). Tai minètas ir iki šiol pasaulyje žaidžiamas žaidimas LARPG. Klubo „Viduramžių pasiuntiniai“ ¡ikūrèjai buvo aktyvūs šios veiklos dalyviai, tačiau ilgainiui pradejo ieškoti kitokio, istorinị pagrindą turinčio, užsièmimo. Tai galima sieti su istorinès rekonstrukcijos formavimosi pradžia, kai atsiranda poreikis naudotis gilesnèmis istorinėmis žiniomis. Istorinès rekonstrukcijos veikla, LARPG atžvilgiu, pateikejjo vertinta kaip „rimtesne““ (VDU ER 2677, anketa Nr. 4). Pamažu klubo „Viduramžių pasiuntiniai“ veikla iš idejjinès peraugo i komercinę. Dèl šios priežasties kilę vidiniai nesutarimai (siekis) lèmè naujų klubų atsiradimą: „Mysteria Mundi“ (nuo 2008 m.) ir „Saltus Gladii“ (nuo 2012 m.). Be to, 2004 m. anksčiau minètame Kauno karo istorijos klube buvo įsteigta Viduramžių sekcija. Pagrindine šios klubo sekcijos kryptimi buvo pasirinktas XIV-XV a. Teutonų ordino ir Lietuvos Didžiosios Kunigaikštystès ginkluotès, šarvuotès ir kovos taktikos atkūrimas (VDU ER 2677, interviu Nr. 26, 2018).

Vèliausiai formavosi XX a. istorinius įvykius atkuriantys klubai. Internetinis forumas Militaria Lituanica ${ }^{11}$ buvo ir iki šiol yra viena iš pagrindinių socialinių platformų, kurioje asmenys, besidomintys Pirmuoju ir Antruoju pasauliniais karais bei pokario rezistencija, gali tarpusavyje diskutuoti jiems rūpimomis temomis ir ieškoti atsakymų į klausimus, kurių nėra istorijos vadovèliuose ir enciklopedijose. Šis forumas tapo pagrindu, padejusiu susiburti pirmiems atitinkamą laikotarpi reprezentuojantiems istorinès rekonstrukcijos klubams. Pateikejjas pasakojo:

Tai buvo karo istorijos radinių, antikvarų forumas, ir jame kilo idejja: „Žiūrèkit, čia, užsieny, žmonès rengiasi kažkokiomis uniformomis ir ginklus iš kažkur gauna. Čia rekonstrukcija vadinasi. “ Ir jie tiesiog susibūrè ir atvažiavo vieną kartą <...> 2008 [metais]. <..> jie pirmą kartą realiai pasimatė, didžioji dalis. [Tuometiniai forumo dalyviai] susivežè, ką turèjo, nusipirkę uniformas, ir taip prasidejjo visas reikalas. <..> Man pasakojo, kad žmonès daugelis net nebuvo gyvai vieni kitų matę. Tiesiog išsinuomojo iš Lietuvos kino studijos ginklus (VDU ER 2677, interviu Nr. 16).

10 „Viduramžių pasiuntiniai“ - brolija. Prieiga internetu: <http://viduramziai.lt/> [žiūrèta 2019 $0522]$.

11 Militaria Lituanica - pokalbių forumas. Prieiga internetu: <www.militaria.lt> [žiūrèta 201904 30]. 
Taip susiformavo svarbiausias ir reikšmingiausias šio laikotarpio grupès klubas „Grenadierius“. Klubas veiklą pradejo 2008 m., tačiau ilgainiui dalis narių atskilo. Buvusio klubo „Grenadierius“ nario iniciatyva ikkurtas klubas „Partizanas“ (nuo 2015 m.). Šio klubo dèmesio centre atsiduria partizano, kovojančio prieš Sovietų Sąungos neteisètus valdžios veiksmus, gyvenimas ir buitis rezistencinio karo sąlygomis. İ pirmą planą iškeliamas tikrų, autentiškų objektų naudojimas, taisyklingas uniformos dejvejimas. Rekonstruktoriai akcentuoja atsiribojimą ir bet kokias sąsajas su politine ideologija. Klubo „Rytprūsiai“ svetainèje nurodoma, jog „klubų nariai susilaiko nuo bet kokio pasirinkto laikmečio politinio idealizavimo"12. Tai būdinga visiems minimo laikotarpio klubams, siekiantiems apsisaugoti, kad į klubą nepatektų radikaliais būdais savo pažiūras reiškiantys asmenys. Ši tendencija nesiskiria nuo vyraujančios užsienyje ${ }^{13}$.

\section{Istorinès rekonstrukcijos judejimokryptys Lietuvoje}

Tyrimo duomenys atskleide, kad Lietuvoje išsiskiria keturios ryškios istorinès rekonstrukcijos kryptys: 1. Baltų; 2. Viduramžių; 3. Napoleonmečio ir 4. XX amžiaus. Remiantis tyrimo rezultatais, buvo sudaryta chronologine juosta, atskleidžianti šiuo metu Lietuvoje rekonstruojamus istorinius laikotarpius (žr. 1 chronologinę juostą). Kaip galima pastebèti, Lietuvoje nèra atkuriamas gana ilgas laikotarpis - nuo XV a. antrosios pusės iki XVIII a. pradžios. Galbūt tokiam pasiskirstymui įtakos turejo tuometinès LDK valstybės buvimas ATR (Abieju Tautu Respublika) sudètyje (nuo Liublino unijos 1569 m. iki Lenkijos konstitucijos prièmimo $1791 \mathrm{~m}$.). Tuo tarpu minèto laikotarpio kultūra pati savaime nėra pasirenkama istorinès rekonstrukcijos objektu. Ši tendencija nėra būdinga tik Lietuvos atveju. Pavyzdžiui, D. Radchenko teigimu, vienas populiariausių laikotarpių Rusijoje - viduramžių Europa ir Napoleono karų epocha (Radchenko 2006, 129). Švedijos rekonstruktoriai teigia, kad populiariausi yra vikingų ir viduramžių laikotarpiai.

1 chronologinejje juostoje buvo išskirta ir amatų rekonstrukcijos kryptis, nes ji „netelpa“ ị vieną iš išvardytų laikotarpių ir apima kelis atkuriamus laikotarpius. Iš chronologinès juostos matyti, kad amatų reikšmė nuo XV a. antrosios pusès pradeda mažèti. Tokia tendencija iš dalies rodo ir technologijų vystymąsi, kai rankų darbas yra pakeičiamas arba papildomas naudojant ịvairius įrenginius.

12 „Rytprūsiai“ - karo istorijos klubas. Prieiga internetu: <http://www.rytprusiai.lt/rekonstrukcija/> [žiūrèta 201904 28].

13 Antrojo pasaulinio karo gyvosios istorijos asociacija (ang1. WW2 Living History Asociation), pradejusi veiklą 1978 m., yra pirmoji tokia Antrojo pasaulinio karo rekonstruktorius vienijanti organizacija. Asociacijos svetainejje nurodoma, kad šios organizacijos veikloje netoleruojamas jokios politikos ísiterpimas (angl. ,we do not allow any political involvement to enter our actions“. Prieiga internetu: <https://www.ww2lha.co.uk/about> [žiūrèta 201905 28]. 
Napoleonikos bei XX a. laikotarpių rekonstrukcijose amatai nėra aktualizuojami. Pirmenybe imama teikti originalams, ypač tai būdinga paskutinio - XX amžiaus - laikotarpio rekonstruktoriams. Nepavykus įsigyti originalų, užsakomos kopijos profesionaliems siuvejams pasiūti ar įmonèms pagaminti.

Eksperimentinès archeologijos klubas „Pajauta“ (2002), atkuriantis keramikos, odos, juvelyrikos bei kitus dirbinius ir kompleksiškai taikantis reikiamas technologijas, reikalingas archeologinių dirbinių kopijoms ${ }^{14}$, yra pavyzdys, rodantis, jog rekonstrukcijos pagrindiniu objektu gali būti pasirenkamas amatas. Amatų kategorijai galime priskirti ir „Dvaro meistrus“15. Iš 1 chronologinès juostos matyti, jog rekonstruktoriams, užsiimantiems atkurti laikotarpi nuo XVI a., amatų, kaip savarankiškos rekonstrukcijos šakos, reikšmė ima mažèti. Tai galima paaiškinti ir technologijų kaita, kai rankų darbas pamažu buvo keičiamas pritaikant įrenginius (pavyzdžiui, siuvimo mašiną). Napoleonmečio ir XX a. laikotarpių rekonstrukcijose amatai nẻra aktualizuojami. Pirmenybę imama teikti originalams, tai populiaru ypač tarp paskutinio - XX a. - laikotarpio rekonstruktorių. Nepavykus įsigyti originalų, užsakomos kopijos iš profesionalių siuvejjų ar įmonių. Kas galèjo turèti įtakos būtent šių laikotarpių populiarumui?

Buvo minèta, kad rekonstrukcijos judejjimą Lietuvoje pirmiausia lèmé politinès ideologijos kaita, leidusi skleistis iki tol slopintiems nacionaliniams jausmams. 1998 m. prasidèjęs naujas muziejų etapas (aktyvi „gyvo“ muziejaus veikla) ir tuometinè kultūros politika skatino viešinti „didžiojo tautos naratyvo“ idèją. Istorinejje kultūroje tuo metu vyraujantị didịji nacionalistinị naratyvą istorikė Agnè Vaitkuvienè sieja su romantizuota S. Daukanto ir A. Šapokos Lietuvos istorijos vizija, kuri papildoma smulkesniais pasakojimais (Vaitkuvienė 2006, 91). Jean-François Lyotard, prancūzų filosofas ir sociologas, postmodernybę apibrèždamas kaip nepasitikejjimą didžiaisiais naratyvais, teigia, jog „didieji pasakojimai“ turètų užleisti vietą „mažiesiems“ (pranc. petits récits), kukliesiems, arba „lokaliesiems“, naratyvams $(1993,6)$. Tiek didžiojo, tiek mažųų naratyvų aktualizavimas vyksta tokių renginių kaip Gyvosios archeologijos dienos (nuo 1999 m.) ir Baltijos jūros regiono senovès genčių karybos ir amatų šventès APUOLE் 854 (nuo 1999 m.) organizavimu, kuriuose akcentuojama dabarties ir praeities kultūra ir jos paveldas. Būtų pernelyg kategoriška teigti, jog šių festivalių dalyviai jau tada suvokė save kaip istorinės rekonstrukcijos judejjimo dalị, tačiau renginių populiarumas, ypač Gyvosios archeologijos dienų, darė stiprią itaką tolesnei istorinès rekonstrukcijos krypčiai. Ir galbūt padiktavo rekonstruo-

14 „Pajauta“ - eksperimentinès archeologijos klubas. Prieiga internetu: <http://www.pajautaclub. lt/> [žiūrèta 20190513$].$

15 „Dvaro meistrai“ - amatininkų klubas. Prieiga internetu: <http://www.dvaromeistrai.lt/> [žiūrèta 201905 14]. 

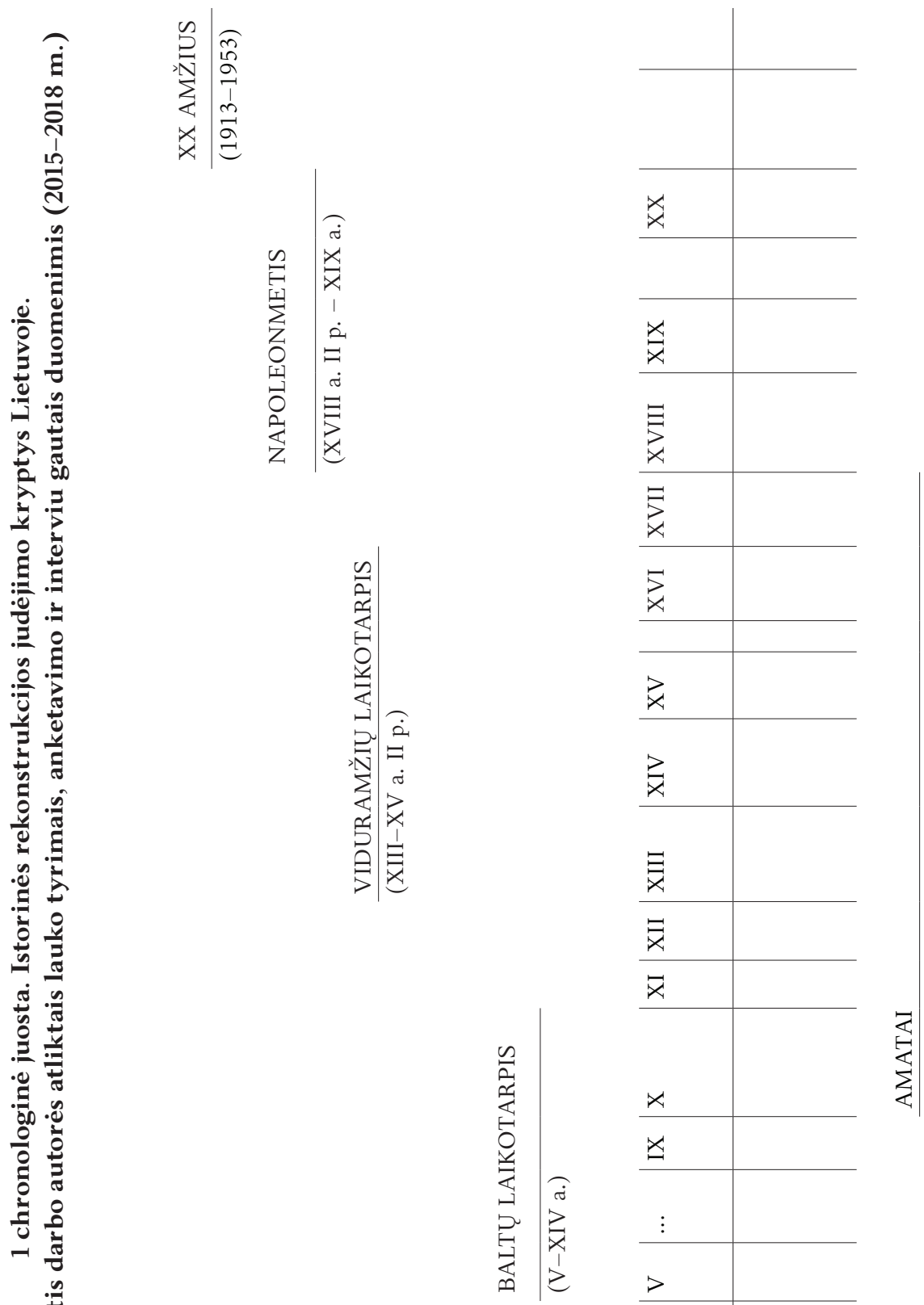

爻

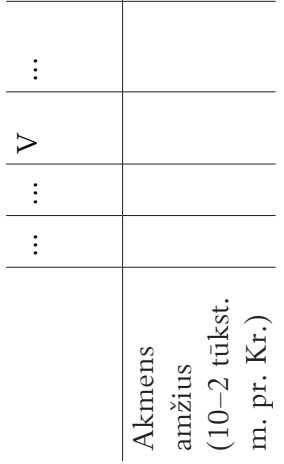


jamų istorinių laikotarpių bei temų populiarumą Lietuvoje. Tuo tarpu mažiausiai visuomenèje pastebimos (renginių atžvilgiu) XX a. rekonstrukcijos. Nors šio laikotarpio renginių sąlyginai mažai, veikla koncentruojasi į klubų narių susitikimus, ekipuotès ir ginkluotės skolinimą kino ir TV serialų kūrèjams (vienas iš paskutinių - serialas „Laisvès kaina“) ar net dalyvavimą filmų kūrimo scenose, pavyzdžiui, filmų „Pavergtųjų sukilimas“ (2011), „Nematomas frontas“ (2013). Dauguma šio laikotarpio Lietuvos rekonstruktoriu klubų dalyvauja užsienyje (pirmiausia Latvijoje, Estijoje, Lenkijoje, Vokietijoje, Baltarusijoje, Rusijoje) vykstančiuose festivaliuose.

2008 m. ekonominè krizè paveikè ir rekonstrukcijos judèjimą. Dalis klubu narių ir laisvųjų rekonstruktorių emigravo, kai kurie klubai nunyko ar sustabdè savo veiklą (pavyzdžiui, „Utgardas“, „Luoka“), dèl to šiek tiek sustojo ir tolesnè viso judejjimo raida. Nauji istorinès rekonstrukcijos klubai daugiausia formavosi tik 2012-2014 m. Pastaraisiais metais istorinės rekonstrukcijos klubų ir laikotarpių įvairovė Lietuvoje išlieka iš esmès nepakitusi, todèl galimas permainas būtų sudètinga įžvelgti ir pačiame judẻjime.

Išvados

Postmodernus istorinės rekonstrukcijos reiškinys, susiformavęs XX a. 7-ajame dešimtmetyje JAV, pasieke tiek Europą, tiek ir likusi pasaulį. Reiškinys netruko virsti judejjimu. Medijų (istoriniai filmai, fantasy žanro literatūra, internetas) sklaida, SCA organizacija ir LARPG judejimas buvo pagrindiniai veiksniai, turèję įtakos šio judejjimo sklaidai ir populiarumui.

Remiantis atliktu tyrimu, istorinès rekonstrukcijos judejjimo pradžia Lietuvoje siekia XX a. 9-ąji dešimtmetį. Atliktas tyrimas parodè, kad istorinès rekonstrukcijos reiškinio idėjos sklaidą paskatino užsienio pavyzdžiai ir LARPG organizacijos veikla. Tačiau nemažai įtakos turejo ir vidiniai politiniai procesai: Lietuvos persitvarkymo sąjūdžio veikla ir $1990 \mathrm{~m}$. Lietuvos nepriklausomybès paskelbimas. Medijos (ypač internetas) ir ryšiu su Latvijos, Estijos, Lenkijos, Rusijos, Baltarusijos rekonstruktorių klubais palaikymas paspartino judejjimo sklaidą ir populiarumą. Reiškinys iš esmès koncentruojasi i istorinès rekonstrukcijos klubų veiklą, tačiau apima ir pavienius asmenis bei su šia kryptimi susijusias organizacijas.

Atlikus analizę, Lietuvoje išskirti keturi pagrindiniai istorinès rekonstrukcijos laikotarpiai: 1. Baltų (pradininkai - „Vilkatlakai“); 2. Viduramžių („Viduramžių pasiuntiniai“); 3. Napoleonmečio („Kauno karo istorijos klubas“) ir 4. XX amžiaus („Grenadierius“). Tuo tarpu amatai dažnai apima kelis laikotarpius 
(baltų ir viduramžių). Tyrimo rezultatai atskleide, jog baltų ir jų genčiu (jotvingių, kuršių) klestejjimo laikotarpis, LDK kūrimosi ir gyvavimo laikotarpis bei partizaninis judejimas yra išskirtinės temos, kuriomis siekiama ne tik pabrèžti Lietuvos didingumą, bet ir etninį ar nacionalinį tapatumą. Individualūs ir grupiniai rekonstruktoriu veiklos rezultatai sujungiami iz vientisą atitinkamo laikotarpio minejjimo, šventės, festivalio formatą. Pirmasis istorinès rekonstrukcijos renginys buvo 1992 m. KIK organizuotas Napoleono persikèlimas per Nemuną ties Jiesios piliakalniu (dar vadinamu Napoleono kalnu).

Panašu, kad postmodernios istorinès rekonstrukcijos judejime naudojama simuliuota istorinè aplinka igalina kalbèti apie kitus galimus šio judejjimo tyrimo aspektus: istorija grindžiamą tapatumo konceptą, kuriamus socialinius ir kultūrinius vaidmenis, taip pat išsamiau analizuoti paties judejjimo raiškos formas.

\section{Santrumpos}

VDU ER - Vytauto Didžiojo universiteto Kultūrų studijų katedros rankraštynas

KIK - Kauno karo istorijos klubas

LARPG - Gyvasis vaidmenų žaidimas (angl. Live Action Role Playing Game)

SCA - kūrybinio anachronizmo bendruomenè (angl. Society of Creative Anachronism)

\section{Literatūra}

Agnew 2004 - Vanesa Agnew. Introduction: What Is Reenactment? Criticism 46 (3), 327-339.

Agnew 2007 - Vanesa Agnew. History's afective turn: Historical reenactment and its work in the present. Rethinking History 1 (3), 299-312.

Anderson 1984 - Jay Anderson. Time Machines: The World of Living History. Nashville: The American Association for State and Local History.

Aleksandravičius 2012 - Povilas Aleksandravičius. Kodèl sunku kalbèti apie Europos tapatybę? Socialiniu mokslu studijos 4 (4), 12-64.

Decker 2010 - Stephanie K. Decker. Being Period: An Examination of Bridging Discourse in a Historical Reenactment Group. Journal of Contemporary Ethnography, June 39 (3), 273-296.

Delis 2006 - Renatas Delis. Neopagonybès judejjimas posovietinèje Lietuvoje - alternatyvus lietuviškumas kaip atsakas modernybei? Lietuvos etnologija: socialinés antropologijos ir etnologijos studijos 6 (15), 187-225.

Gapps 2002 - Stephen Gapps. Performing the past: a cultural history of historical reenactments. Filosofijos krypties daktaro disertacija, apginta 200203 31. Technologiju universitetas. Sidnèjus, Australija.

Gapps 2009 - Stephen Gapps. Mobile monuments: A view of historical reenactment and authencity from inside the costume cupboard of history. Rethinking History 13 (3), 395-409.

Handler, Saxton 1988 - Richard Handler, Wiliam Saxton. Dyssimulation: Reflexivity, Narrative, and the Quest for Authenticity in "Living History". Cultural Anthropology 3 (3), 242-260. 
Kobiałka 2013 - David Kobiałka. The Mask(s) and Transformers of Historical Re-enactment. Current Swedidish Archeology 21, 141-161.

Laycoc 2015 - P. Joseph Laycoc. Dangerous Games: What the moral Panic over Role-Playing Games Says about Game, Religion and Imagined Worlds. University of California Press.

Lyotard 1993 - Jean-François Lyotard. Postmodernus būvis. Šiuolaikinị žinojima aptariant. Vilnius.

Micula 2015 - Maja Micula. Historical re-enactment: narrativity, affect and the sublime. Rethinking History 4, 583-601.

Manson 2004 - Jennifer Manson. Personal Narratives, Relational Selves: Residential Histories in the Living and Telling. The Sociological Review 52 (2), 162-179.

Radchenko 2006 - Daria Radchenko. Simulating the Past: Reenactment and the Quest for Truth in Russia. Rethinking History 10 (1), 127-148.

Ramanauskaite 2002 - Egidija Ramanauskaitè. Neopagoniškųjų identitetų konstravimas Lietuvos jaunimo undergroundo kultūroje. Lietuvos etnologija: socialines antropologijos ir etnologijos studijos 2 (11), 89-124.

Sutkaitis 2010 - Tomas Sutkaitis. Senovès ir dabarties baltų kariai. Liaudies kultūra 4, 52-67.

Kalèdienè 2018a - Agnè Kalèdienè. Naujuju baltu subkultūrinio lauko atsiradimas ir raida. Etnologijos krypties daktaro disertacija, apginta 2018-09-21. Vytauto Didžiojo universitetas, Kultūrų studijų katedra. Darbo vadovė doc. dr. Egidija Kiškina.

Kalèdienè 2018b - Agnė Kalèdienė. Historical reconstruction groups in Lithuania: searching for identity in post-socialist society. Balkan and Baltic States in United Europe: Histories, Religions and Cultures II, 231-243.

Vaitkuvienė 2006 - Agnė Vaitkuvienè. Paveldo industrija Lietuvoje. Lietuvos istorijos studijos 17, 87-96.

\section{Šaltiniai}

Alkas - naujienuc portalas. Prieiga internetu: <http://alkas.lt/2015/09/18/kviecia-kasmetine-istorine-rekonstrukcija-medininku-pilyje/> [žiūrèta 201811 20].

Bancheto Musicale - muzikos ir šokiu ansamblis. Prieiga internetu: <http://banchettomusicale. lt/> [žiūrèta 201905 15].

Dvaro meistrai - amatininkų klubas. Prieiga internetu: <http://www.dvaromeistrai.lt/ > [žiūrèta 201905 14].

Delfi - naujienų portalas. Daiva Jankauskaitè. 2007. Suaugusių žmonių žaidimas - grįžti ị praeitį. Prieiga internetu: <http://www.delfi.lt/pramogos/kultura/suaugusiu-zmoniu-zaidimas-grizti-i praeiti.d?id=14315484\#ixzz3VFeQagla> [žiūrèta 201905 15].

Grenadierius - karo istorijos klubas. Prieiga internetu: <http://www.grenadierius.lt/lt/apie-mus $>$ [žiūrèta 201904 05].

Manoapklausa.lt. - apklausos svetainė, kurioje buvo skelbta anketa „Istorinė rekonstrukcija Lietuvoje“. Prieiga internetu: <http://www.manoapklausa.lt/apklausa/826847747/1/> [žiūrèta 201904 25].

Militaria Lituanica - pokalbių forumas. Prieiga internetu: <www.militaria.lt> [žiūrèta 201904 30].

Pajauta - eksperimentines archeologijos klubas. Prieiga internetu: <http://www.pajautaclub.lt/ > [žiūrèta 201905 13].

Rytprūsiai - karo istorijos klubas. Prieiga internetu: <http://www.rytprusiai.lt/rekonstrukcija/> [žiūrèta 201905 10].

SCA - kūrybinio anachronizmo bendruomenè (angl. Society of Creative Anachronism) organizacijos interneto svetainè [interaktyvi]. Prieiga internetu: <http://www.sca.org/> [žiūrèta 201709 09].

Utgardas - gyvosios istorijos klubas. Prieiga internetu: <http://www.utgardas.lt/?kur=apiemus $>$ [žiūrèta 201904 02]. 
VDU ER bylos Nr. 2677 - Kultūrų studijų katedros el. duomenų bazė.

Viduramžiu pasiuntiniai - brolija. Prieiga internetu: <http://viduramziai.lt/> [žiūrèta 201905 22].

Vilkatlakai - senovès baltų kovų brolija. Prieiga internetu: <http://www.vilkatlakai.lt/veikla> [žiūrèta 20190402$].$

Voruta - nacionalinis Lietuvos istorijos laikraštis. Prieiga internetu: $<$ http://www.voruta.lt/isorines-rekonstrukcijos-brolija-vilkatlakai/> [žiūrèta 201812 20].

WW2 Living History Asociation - Antrojo pasaulinio karo gyvosios istorijos asociacija. Prieiga internetu: <https://www.ww2lha.co.uk/about> [žiūrèta 201905 28].

\section{Gintarè Dusevičiūtè-Neimontienè}

\section{THE POSTMODERN HISTORICAL REENACTMENT MOVEMENT IN LITHUANIA}

Summary

Different forms of historical reenactment had a long history before it was considered postmodern. Postmodern historical reenactments started in the 1970s in the USA. They spread first to Europe, and then reached the rest of the world. Aspects concerning the historical reenactment movement, such as authenticity and the use of material culture, narrativity or identity, have been analysed by several authors. So far, there are not many studies on the development and spread of the historical reenactment movement at a local level. During this last decade, the historical reenactment movement has become a constant and usual part of events concerning the historical subject. Nevertheless, the historical reenactment field has not inspired a deeper interest among researchers. Can national features of the historical reenactment movement be distinguished in a Lithuanian context?

The object of this research is the historical reenactment movement and the circumstances of its formation in Lithuania. The aim of the article is to survey the beginning of the postmodern historical reenactment movement in the world, by defining the impact of the main organisation; and after defining the historical reenactment movement, to analyse the main features of the phenomenon in Lithuania. The features of the movement are analysed in the formation of the first historical reconstruction clubs and the first festivals. The basis of this work is fieldwork material collected between 2015 and 2019. Various festivals, celebrations and other events concerned with historical reenactments were attended (23), as well as participatory observations, interviews, and questionnaires with 63 respondents. The data was processed by applying historical comparative and analytical methods.

According to the data received, the historical reenactment movement in Lithuania started in the 1980s. It was influenced by Lithuania's restitution of 
its statehood in the 1990s after its suppression by the Soviet Union, and the desire to properly present the long history of the state. The folklore movement that started around the 1970s still was in existence, and influenced the start of the historical reenactment movement. The media (especially the Internet) and relations with foreign clubs (in Latvia, Poland, Estonia, Belarus and Russia) increased the development and popularity of the movement.

The analysis of the data has indicated the following main historical reenactment periods: the Balts, the Middle Ages, the Napoleonic era, the First and the Second World War, and the resistance. In the reenactment of general themes (such as Medieval), local, regional and national history and artefacts are applied. The first club in Lithuania, called Kaunas War History Club, was founded in 1989. Historical reenactments by this club related to the Napoleonic era. Later, the Balt period with the Vilkatlakai club (from 1996), and the Middle Ages with the first Viduramžiu Pasiuntiniai club, started historical reenactment activities. The First and the Second World War and the resistance movement were reenacted by the Grenadierius club (in 2008). In the reenactment of general themes (such as Medieval), local, regional and national history and artefacts are applied. The period of the Balts and Baltic tribes (Yotvingians, Curonians), and the period of the creation and prosperity of the Grand Duchy of Lithuania and the partisan resistance, are themes by which the historical reenactment movement stands out. 